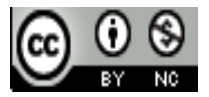

Journal of Education, Teaching, and Learning is licensed under A Creative Commons Attribution-Non Commercial 4.0 International License.

\title{
The Development of Science Learning Module with Problem Solving Method
}

\author{
Patriksius Arpan ${ }^{1)}$, Aunurrahman ${ }^{2)}$, Fadillah $^{3)}$ \\ ${ }^{1)}$ Universitas Tanjungpura, Pontianak, Indonesia \\ E-mail:arpanpatriksius@gmail.com \\ ${ }^{2)}$ Universitas Tanjungpura, Pontianak, Indonesia \\ E-mail: aunuruntan@gmail.com \\ ${ }^{3)}$ Universitas Tanjungpura, Pontianak, Indonesia \\ E-mail:fadillahkn@gmail.com
}

\begin{abstract}
This study aims to produce science learning modules with Problem Solving methods that will be used in science learning plant breeding materials, can implement the science learning module Problem-Solving methods and describe the learning outcomes of plant breeding materials using method Problem-Solving in State Elementary School 03 of Hulu Sungai in Ketapang Regency. This research is the development of science learning method using Problem-Solving method by using the development phase of R \& D Research adopted by Borg and Gall with module design using ADDIE model, with the research subject is class VI involved 16 students Data obtained through expert design validation questionnaire, expert media materials and experts, interviews, student response questionnaires, and documentation. Furthermore, data analysis is conducted qualitatively and quantitatively.
\end{abstract}

Keywords: Development; Module; Problem Solving

\section{INTRODUCTION}

The effort that can be done to improve the quality of students is through the learning process. A good learning process is when a teacher plays an active role, and the learning process can motivate students to think and learn the subject matter. The success of a learning process depends on several factors supporting learning, both regarding students and from the side of the teacher. Therefore the success or failure of a learning process can also be due to existing factors that do not function properly in influencing behavior change in learning.

With the development of science and technology today, it is very influential on the process and development of education, improving the quality of education is one of the things that are prioritized by the government. It refers to the national education standard policy, namely PP number 19 of 2005 article 20 which implies that the teacher is expected to develop the learning process and learning material and to arrange the planning of the learning process by developing indicators of SK and KD into the RPP. The implementation of this policy requires teachers to be able to prepare various needs for the learning process so that learning objectives can be achieved optimally.

The learning process is the process of communication between the teacher and students, students with students to be able to establish good and smooth interactions. The learning process is highly dependent on the teacher in utilizing strategies to gain success and success, as stated by Hamruni (2012: 1), that "Strategies are used to gain success or success in achieving goals."

Besides strategies also need to pay attention to learning media as a learning resource. One way to facilitate students to create the effectiveness and absorption of learning materials is the existence of learning modules and the use of learning media. The use of this media is through the development of innovative, creative and interactive media. Learning media is an important factor in learning because the media is an intermediary that can help carry out the learning process. There are some media as learning resources that develop like print media in the form of modules. 
Modules are learning tools or suggestions that contain material, methods, boundaries of learning materials, instructional instructions, exercises and how to evaluate competencies that are expected and are designed systematically and interestingly to achieve the expected competencies and can be used independently (Hamdani, 2011: 219 ). The module is a tool or means and is one of the printed-based learning media designed to study independently by students. Therefore the module contains learning material that is packaged into more specific units to facilitate learning independently can do learning activities anytime and anywhere. The learning module can provide learning experiences that are planned and systematically designed to achieve learning goals. The learning process of using modules will make learning more efficient, effective and relevant compared to conventional learning which tends to be more teachercentered and less interaction with student.

In the module there is an advantage in the form of self-intervention that allows students to be independent learning and the teacher is not the only source of learning for students themselves. The use of this learning module is very good when used by teachers and students in the learning process because it will facilitate students to understand the material, involving the active role of students and independently through the use of learning modules. The active role of students is very necessary for the learning process and each subject. Subjects in elementary school (SD) one of which is a science subject. Science subjects are one of the subjects that study the phenomenon of the universe.

In Science subject, there is material for Plant Breeding, where this material is found and studied by the sixth-grade students and precisely in the even semester. After studying the breeding material, students are expected to develop the abilities of the students themselves, including skills, creativity, initiative, and responsibility. In addition, developing knowledge about the science of Plant Breeding among students in order to be able to apply and develop in daily life, so that in science learning in schools is expected to be more effective in realizing these goals.

In science subjects this Plant Breeding material if it is understood it will be so interested in getting deeper. However, the facts in the field show that the science lesson on Plant Breeding material is very difficult to understand or understand by students so that students assume that this material is not interesting to learn. Facts in the field of many schools that have not applied print media as a source of learning, especially learning modules.

The assumption that the science subject matter of Plant Breeding is classified as difficult to understand is also experienced by the sixth-grade students of State Elementary School 03 of Hulu Sungai in Ketapang Regency which there are still many students feel confusion in absorbing material and difficult in solving problems in the material.

From the experience of teaching science subjects over the years and the results of discussions with colleagues who both taught science subjects, obtained information that in the learning process of science classified as difficult, the material of this proliferation can be seen from the students' daily test scores for the 2017/2018 school year. It does not achieve the desired learning goals. He also explained that at the time the learning process took place it had never used learning media as a learning resource, especially modules.

Teachers and students only use Science book to handle the teacher as a learning resource. It is due to the limitations of school facilities, the absence of a library in schools so that the textbooks are not available. The interviews were also conducted by researchers to students in class VI and information was obtained that they thought that Breeding material was difficult to understand.

Direct observation or observation conducted by researchers in class VI of State Elementary School 03 of Hulu Sungai in Ketapang Regency, during the learning process, obtained information that the learning carried out only used the teacher's handbook, the explanation on the Breeding material was incomplete, and the students did not have a textbook. In the delivery of material, the teacher uses conventional methods and tends to when learning takes place often students find it difficult to concentrate because they are disturbed by other students. Students do not focus and talk to their friends, do not record and do not pay attention to the teacher's explanation.

Students' lack of understanding in the absorption of this material so that the learning outcomes obtained do not reach the learning objectives. It is illustrated by the results of the daily grades of the sixth-grade students for the material of Plant Breeding with competency standards (KD) Interpreting Plant Breeding. Based on the data obtained by the achievement of students' completeness in science subjects the material of Plant Breeding was classified as low. The success or failure of students in science learning about Plant Breeding material is due to various factors. Namely, the assumption about Plant Breeding material is difficult to learn material; classical learning only reaches the minimum completeness criteria of $38 \%$ for the $2016 / 2017$ school year and $37 \%$ for the 2017 academic year / 2018.

From the description above, it shows that the problem of low learning outcomes and lack of response from students when learning takes place is because there is no use of learning resources that can further activate students and lack of motivation for students to learn. With the existence of these problems, it can be ascertained that the learning 
outcomes of some students on each daily test will not reach the minimum completeness criteria (KKM).

Efforts to achieve learning objectives and overcome these problems is the need for a quality science learning design so that students are encouraged to learn by better understanding the material being taught. The design of learning is in the form of media that is used as a source of learning.

With the learning, module is expected to attract students' interest, and facilitate students in absorbing material. The learning module that will be designed by the researcher is the science learning module based on student characteristics guidelines and will be adjusted to the students' needs. With this module, students will carry out an interesting learning process. Science learning modules with problemsolving methods have special characteristics namely performance or demonstration activities.

The implementation of problem-solving methods is often followed by an experimental method, which is an experiment about something, in this case, an experiment on Plant Breeding. With the experiment will clarify the results of learning because each student experiences to conduct experiments, this is a modern theory of learning by doing.

Based on the background described, it is this that encourages researchers to carry out development research in the form of 'Development of Science Learning Modules with problem-solving methods To Improve Learning Outcomes of Plant Breeding Materials in class VI of State Elementary School 03 of Hulu Sungai in Ketapang Regency Academic Year 2017/2018".

\section{RESEARCH METHOD}

Nawawi (2012: 65) suggests that "the method means the method used to achieve the goal." Furthermore, Sukmadinata (2005: 52) stated that "the research method is a series of ways or activities to carry out research based on basic assumptions, philosophical and ideological views, questions and issues faced."

The type of method in this study is the development research ( $R$ \& D) method as stated by Sugiyono (2012: 4077) that: Research and development methods or research and development are, "research methods used to produce certain products, and test the effectiveness of these products." This study aims to develop a learning product that can facilitate students in the learning process with learning outcomes that are appropriate to the learning objectives. The product is a printed learning media in the form of a science learning module with problemsolving methods in science subjects of Plant Breeding material which will be used as a learning resource by Grade VI students of State Elementary School 03 of Hulu Sungai in Ketapang Regency.
In the development research that the researcher will do, researchers use a type of descriptive approach, which is used to describe in detail the data obtained in a naturalistic manner based on research procedures.

Research Procedures used in this development research are based on development research according to Borg and Gall. Development research is a process used to develop and validate educational products.

In development research, it is better to do this by limiting research on a small scale, including the possibility of limiting the steps of research. The research procedures carried out by the researcher in this development were adapted from Borg and Gall's development procedure, so the researchers limited the steps of research on a small scale tailored to the needs of researchers.

The research procedure carried out by the researcher in this development was adapted from the Borg and Gall development procedure with the design of the module design namely the ADDIE model. In the module development design consists of a) Research phase and data collection, b) Planning phase, c) Development phase of learning modules, d) Expert validation phase, e) Trial phase and f) Stage of final product improvement.

So the researcher simplifies into 4 (four) steps of development. The development steps that will be carried out by the researcher are as follows:

a. Research and Data Collection

b. Planning phase

c. Product development stage

d. Validation and Trial Phase

A. Result

1. Research and Data Collection Phase

Data analysis conducted by researchers in the data collection stage is to conduct literature studies and field studies related to the problems studied and supporters for the basis of developing. Observation activities were carried out at Public Elementary School 03 in Hulu Sungai District, Ketapang Regency. To know the real conditions in the field. This stage enters the analysis phase in the Addie model. The results of this stage are:

a. Needs Analysis

In this study, needs analysis is done by digging and collecting important information related to the problems that occur in science learning for sixth-grade students of Public Elementary School 03 in Hulu Sungai District, Ketapang Regency. The results of this analysis are obtained through observation and interviews. Based on the results of observations and interviews conducted with a science teacher, information was obtained that the role of teachers was still very dominant in science learning in the 
classroom. Other information obtained is based on the average daily test results for the 2017/2018 school year, which is still low, especially in the case of Plant Breeding. Teachers are still having trouble finding teaching materials that can facilitate this. Therefore, it is necessary to make an effort that can overcome these problems, namely developing science teaching materials as learning resources that can help in the learning process, one of which is the print media in the form of learning modules.

\section{b. Curriculum Analysis}

Curriculum analysis is carried out by analyzing competency standards and basic competencies as well as competency achievement indicators by referring to the Education Unit Level Curriculum (KTSP). The material chosen to be developed in the module is plant breeding material. Plant breeding material because based on the results of discussions with the teacher that is known that the concept of plant breeding is a material that is quite difficult to understand by students, this is also based on the results of the $2016 / 2017$ and 2017/2018 learning values of many plant breeding materials that do not reach maximum completeness (KKM).

c. Student Characteristics Analysis

Characteristic analysis of students aims to determine the characteristics of students who will use the developed learning modules. Analysis of students is carried out to determine the characteristics of students in class VI Elementary School 03 in Hulu Sungai District, Ketapang Regency. The analysis is carried out as long as the researcher carries out observation activities. From the results of the analysis, it was found that the sixth-grade students had diverse abilities. It can be seen in learning such as:

1) There are students who ask the teacher if they meet confusion.

2) Students are less active in learning. It can be seen in their activities while learning in the classroom. There are several students who are busy in the classroom and do not pay attention when the teacher explains in front of the class, as well as students who actively answer questions, do assignments on the board only certain students.

3) Students feel difficulties in completing exercises about plant breeding.

4) The learning process in the classroom still uses the lecture method, namely the teacher explains then the students listen, record, and do the assignments according to the teacher's instructions.

5) The teaching materials used in class are only those set by the school.

From the results of the analysis carried out by the researcher, it can be concluded that the learning process carried out at the State Elementary School 03 of Hulu Sungai in Ketapang Regency is not optimal. So the researchers want to make a change in the learning process so that students can learn more independently and actively, especially in science subjects of plant breeding material by floating a print media in the form of learning modules that can be used as learning resources that can provide improvements in the learning process in public State Elementary School 03 of Hulu Sungai in Ketapang Regency.

2. Planning phase

This second stage is planning where in this stage is included in the second stage of the design plan of the science learning module with the problem-solving method, with the ADDIE design namely the Design stage. The initial design of the module design is as follows:

a. Formulate learning objectives

Learning objectives are statements about what is expected to be mastered by students after learning or after completing a teaching material module. Efforts to formulate learning objectives can provide certain benefits, both for teachers and students. Benefits of learning goals, namely:

1) Make it easy to communicate the purpose of teaching and learning activities to students, so that students can do their learning activities more independently

2) Make it easy for teachers to choose and compile teaching materials

3) Helps facilitate teachers in determining learning activities and learning media

4) Make it easy for the teacher to make an assessment.

The learning objectives to be achieved are that students are expected to be able to:

1) Describe plant breeding

2) Distinguish the ways of breeding

3) Understanding the process of breeding of the plants concerned

b. Determine the content and order of learning material

1) Identification of the main topics, concepts, principles, theories that will be presented in the module.

2) Describe the subject matter in the sub-subject matter. It is done with the aim of:

a) The material to be presented is relevant to the purpose of formulated learning

b) In accordance with the level of student development.

c. Test preparation

The design and preparation of test instruments based on learning objectives with the aim of knowing the level of mastery of students. Assessment that is done is cognitive assessment. 
The test forms used are multiple choice objectivity tests, right and wrong and essays.

3. Product development stage

The product to be developed is the print media in the form of learning modules. Modules as a medium of delivery in the learning process have been used as a foundation of hope to be able to change the situation of the learning situation in order to activate students and be able to learn independently, so that modules must be designed or designed in such a way that students are interested in the science learning process, especially plant breeding material. In the next stage, the module development phase. The implementation of development with several stages which include:

\section{1) Module Preparation Based on Content Aspects}

The sequence of module development based on the content aspect refers to the writing systematics that is based on the elaboration of the basic competency and competency standards that have been set into indicators. The systematics of writing is then translated into several learning activities.

Table I

Material Distribution in Modules

\begin{tabular}{ll}
\hline \multicolumn{1}{c}{ Learning Activities } & \multicolumn{1}{c}{ Material in Module } \\
\hline 1. The concept of breeding plant & $\begin{array}{l}\text { A. Definition of general breeding } \\
\text { and plant breeding. }\end{array}$ \\
\hline 2. The shape and type of plant breeding & $\begin{array}{l}\text { B. Forms and examples of plant } \\
\text { breeding }\end{array}$ \\
\hline 3. Breeding process process & $\begin{array}{l}\text { C. The breeding process is in } \\
\text { accordance with the type. }\end{array}$ \\
\hline
\end{tabular}

2) Module Preparation Based on Aspects of Presentation \& Integrity

The preparation of modules from the aspects of presentation and graphics must pay attention to and be adjusted to the module framework that has been set. Products developed by researchers have components that aim to facilitate students in the learning process and in understanding the material. The components will be discussed in more detail as follows:

a) Cover Page

The cover module design contains the module title, subject matter, illustration of breeding, the year the module was done and the name of the author/author of the module.

b) Introduction to the Author and Preface

The next page is the introduction to the author which contains information about the role of the module that has been designed by the author from the background process of the author's interest in the development of the module, to the process of validity of the module so that the learning module is suitable to be used in the learning process that is equipped with a preface containing the utterances of the author for the completion of the learning module product.

c) Table of contents

The next page, the table of contents, contains the material of the module, the details of the learning activities and the module framework and is equipped with a page number.

d) Concept map

Furthermore, the concept map shows the position between sub-material with one another in full, to facilitate the module reader to understand it.

e) Preliminary design

The introductory section consists of an introduction to the competency standard, the basic indicator competencies contained in the module to be studied in the learning process, the module usage instructions contain guidelines for using modules, the learning objectives include the objectives to be achieved after using the learning module with the problem-solving method, the description contains explanations short of the contents of the module, the prerequisites contain the requirements to master the previous material, the initial ability check contains a list of questions that will measure the initial mastery of students' competencies on the competencies to be learned in the learning module.

f) Content section

The design of learning activities consists of three learning activities which contain material based on indicator I, indicator II and indicator III. In learning activities also contain material descriptions.

g) Cover Design

In addition, the final part of the design contains an evaluation. Evaluation activities must be carried out by students to determine the level of success of the absorption of material that is done independently. In the end, there are also key answers that contain answers to evaluation questions, glossaries, and bibliography.

3) Module Preparation of Linguistic Aspects

The language used in the preparation of this module is Indonesian

4) Validation and trial phase

a) Validation

Validation phase is done so that the developed learning module can be known for its feasibility based on the assessment of design experts, material experts and module experts. Validation is carried out by:

(1) Competent design experts in the design of learning modules. 
(2) Material experts who are competent in the field of science, especially plant breeding materials and

(3) Media experts who are competent in the field of learning media.

(1) Results of Designation Expert Evaluation

Before conducting the test, the learning module developed was also validated in advance by design experts, especially the design of the learning module. Module design validation is carried out by Mrs. Dr. Indri Astuti, M.Pd who has a background in accordance with the modules developed.

Validation by module design experts aims to get information, criticism, and suggestions so that the learning module is developed into a quality product regarding graphic feasibility. The results of the validation can be seen in table 4.4 The products that have been validated are then revised according to suggestions and expert input during the validation process.

Based on the results of the validation, the average score of the module design expert evaluation analysis is obtained as follows:

Table II

Results of Data Analysis Module Design Experts (Graphic Feasibility)

\begin{tabular}{clcc}
\hline No & \multicolumn{1}{c}{ Indicators } & Average & $\begin{array}{c}\text { Qualitative } \\
\text { Criteria }\end{array}$ \\
\hline 1 & Display Aspects & 4,0999 & Very Good \\
\hline 2 & $\begin{array}{l}\text { Conformity Aspects of } \\
\text { Material }\end{array}$ & 2,90 & Good \\
\hline \multicolumn{2}{l}{ Average } & 3,49 & Good \\
\hline
\end{tabular}

The eligibility criteria of the science learning module are obtained by converting qualitative data in the form of scores for each aspect of feasibility and total score into the feasibility conversion table so that qualitative results are obtained in the table.

The aspect of the cover display has good qualitative criteria with the average value of the assessment item is 4.09. In this aspect, there is a comment module that is quite good and interesting while the advice given is; so that the writing is only colored with black, the use of images can be in accordance with the illustration of plant breeding and the writing is more clarified. Aspects of conformity in the material content of the module have good qualitative criteria with an average value of 2.90 teaching material assessment items so that it can be concluded that the conformity aspect of the module material has quite good content and is consistent and harmonious. Thus, this module is feasible based on aspects of suitability.

The two aspects assessed by the validator, it has an average value of 3.49 , which means that the design of the learning module that has been made is good and can be used in the science learning process of plant propagation material.

Therefore, based on data analysis conducted from module design experts, the teaching materials in the form of learning modules developed can be said to be valid, although there are still those that must be revised according to the validator's advice or module design expert lecturers.

(2) Results of Assessment of Material Experts

Material validation was carried out by the science teacher of Pontianak City State 1 High School, named Mrs. Sri Supartini, M.Pd who had a background in accordance with the material developed. Validation by material experts aims to get information, criticism, and suggestions so that the learning modules are developed into quality products in the material, learning, and linguistic aspects. Validation is carried out starting April 20, 2018.

Based on the results of the validation obtained the average value of the analysis of expert assessment of the material as follows:

Table III

Results of Analysis of Science Expert Assessment

\begin{tabular}{llcc}
\hline No & Assessment Aspects & Average & Qualitative Criteria \\
\hline 1. & Aspects of Material Contents & 3,38 & Good \\
\hline 2. & Learning Aspects & 3,40 & Good \\
\hline \multicolumn{2}{l}{ Average } & 3,39 & Good \\
\hline
\end{tabular}

Validity criteria for teaching materials are obtained by converting the total score of each aspect of the feasibility conversion table. The complete calculation can be seen in the attachment.

Judging from the feasibility of the content, every aspect assessed in the material developed has met the eligibility criteria because the material used is good in accordance with SK and $\mathrm{KD}$, the material is quite accurate, has good learning support material through material updates, fulfills the aspects of presentation, and material presented accordingly.

Therefore, based on data analysis carried out from the Material Expert, the instructional material developed has a total average score of 3.39 with good and valid qualification criteria, although there are still many things that must be revised in accordance with the suggestions and comments from the validator.

(3) Results of Media Expert Assessment

Before conducting the test, the learning module that was developed was also validated in advance by instructional media experts. Validation of learning media was carried out by Mr. Dr. Dede Surachman who has a background 
in accordance with the media from the developed module.

Validation by media experts aims to get information, criticism, and suggestions so that the media is made as a learning module that is developed into quality products regarding graphic feasibility.

Based on the results of the validation, the average score obtained from the analysis of expert material assessment is as follows:

Table IV

Results of Media Expert Data Analysis

\begin{tabular}{clcc}
\hline No & \multicolumn{1}{c}{ Indicators } & Average & Qualitative Criteria \\
\hline 1 & Display Aspect & 3,33 & Good \\
\hline 2 & Conformity Aspect Material & 4,00 & Very Good \\
\hline & Average & 3,66 & Good \\
\hline
\end{tabular}

The eligibility criteria for instructional materials were obtained by converting qualitative data in the form of scores for each aspect of feasibility and total score into the feasibility conversion table so that the qualitative results in the table were obtained. Calculations in the feasibility table can be seen in the appendix.

Judging from the components of the size of the instructional material, the module has good qualitative criteria with average grading 3 points so that it can be concluded that the module has a size of teaching material that is in accordance with the material content of the developed teaching materials. The display aspect of the module has good qualitative criteria with an average score of 3.33 grading points. In the cover design is revised because the use of the image is not in accordance with the background and color of the illustration of plant propagation and the writing is more clarified. The suitability aspect of the module material has very good qualitative criteria with an average value of 4.00 teaching material grading items so that it can be concluded that media design has a consistent and harmonious design. Thus this media is suitable for use.

Therefore, based on data analysis conducted by Media Experts, the developed teaching materials can be said to be valid, although there are still many things that must be revised according to the advice of a Media Expert lecturer.

b) Trials

Field trials are the 4th phase of the module design namely implementation. The trial was conducted to measure and determine the feasibility of the module based on the responses and responses of students of State Elementary School 03 of Hulu Sungai in Ketapang Regency. Besides this test is used to obtain information whether the use of learning modules on problemsolving methods of plant propagation material in the learning process is more effective and influences the improvement of learning outcomes than using previous learning resources. The trial was conducted in two stages, grouped into small groups and large groups.

(1) Small Group Trial

The trial was conducted on May 2, 2018, at 8:30 a.m. The product being tested is a revised product based on input from experts. Trial assessment includes aspects of modules, materials and learning media. Data retrieval is done using questionnaire responses of students when using modules in learning. At this stage, a small-scale field trial with four students was selected based on the students' grades grouped based on low ability with moderate and high ability.

Based on the results of the student response questionnaire, it can be concluded that the science learning module with problem-solving methods is good, but for clearer and easier to understand it still needs to be improved.

(2) Test large groups

The learning module which after being tested in a small group, is then tested in the field on a large scale, the research subjects are 16 students, the implementation of the trial is also carried out in large groups, namely each group totaling eight students. There are suggestions and comments made as revisions by researchers to improve the module. Revisions are made to minimize the lack of modules so researchers can make improvements for further research. After the revised module was re-tested in large groups. At this stage, there were 16 large-scale field trials.

Based on the results of the student response questionnaire on a large scale test it can be concluded that the science learning module with Problem Solving method has a very large improvement in this improvement seen from the average total value of the students' response is 3.15 with good information.

Based on this, it can be concluded that the science learning module with Problem Solving method can be a very effective, independent learning resource and can solve problems in the learning process, especially plant breeding material, this is evidenced by students who provide very positive comments and suggestions.

From the results of the trial of small groups and large groups can be seen the comparison in the following graph: 


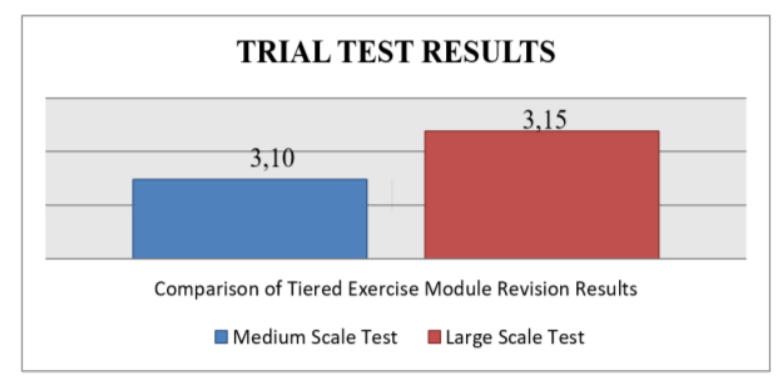

Fig. 1 Comparative Graph of Test Results

Based on the graph above, it can be seen that there has been an increase in the value of the revised result, namely from the results of the medium scale trial of 3.10, the value of the largescale test results with a value of 3.15 with a good category so that the tiered training module is getting closer to the perfect stage and is suitable for use in learning process in class.

2. Implementation of the Science Learning Module Plant Breeding Materials

The development of science learning modules in State Elementary School 03 of Hulu Sungai in Ketapang Regency in this study was carried out through two field trials. Before the trial process, do the pretest first to find out the initial ability of the subject, after that it was tested. The first test was conducted in a small group class consisting of 4 students and a large group of 16 students divided into two groups. The summary of the learning carried out is as follows:

a. Small Group Implementation

Before entering the lesson of breeding plant pre-test conducted to determine the initial ability of students. Learning activities in the learning condition of students and teachers enter the class on time. The teacher immediately takes over during the activation process by giving an opening greeting, and the teacher asks the student's condition. After that, the students are introduced to the science learning module with Problem-solving method, Delivering learning objectives. Students work on the ability check in the module.

The next activity is, students are divided into heterogeneous groups consisting of 3 people. These small groups will be the discussion team in learning on plant breeding material discussed in indicator 1, which is understanding the development procedures and problem-solving methods and indicator II, namely interpreting breeding generatively and vegetatively, at the end of learning students are given formative tests to find out how much students understand the material.

The second meeting, before the learning took place students were given feedback about the previous indicators. After that, the students were grouped back into small-scale groups totaling four people. This small group will discuss the concept of plant breeding to find out what concepts can be used to breed and can apply it in daily life. After that student are given an overview of the ways of plant propagation.

At the end of learning, students are given an evaluation to find out how much students understand the material and post-test to find out the initial conditions with the final condition whether there is a difference, then given a questionnaire on students' responses to the module and the module readability questionnaire for the effectiveness of the module.

b. Large Group Implementation

The implementation of the science learning module was carried out in the sixth grade of State Elementary School 03 of Hulu Sungai in Ketapang Regency as many as 16 students (large class). In principle, the implementation of teaching and learning activities in this large group is the same as teaching and learning activities in small groups, only the subject of research increases, accompanied by improvements in the required parts. This improvement is based on inputs during implementation in small groups.

Some improvements that have been made are improvements to the module including the module cover, the contents of the module, the color of the writing and its application in everyday life in the hope that the module will be more interesting and easy to understand.

3. Learning Outcomes After Using the Science Learning Module Plant Breeding Materials

Student learning outcomes are very important because to know the success of students' learning of plant breeding material. Students are declared complete or mastered the material regarding cognitive if the student learning outcomes are at least 70 based on the reference of the minimum completeness criteria (KKM) of science subjects. Learning outcomes using science learning modules with methods Problemsolving plant breeding material can be seen as follows:

a. Pre-test

The pretest was conducted at the beginning of learning activities. Written tests are taken before learning activities using the module are carried out. The completeness criteria are at least based on the reference of the minimum completeness criteria (KKM) of the school for science subjects, namely 70 .

b. Post-test

Post-tests are carried out at the end of the learning activities that have been carried out. Written tests are taken after the activity of using the module is completed. The completeness 
criteria are at least based on the reference of the minimum completeness criteria (KKM) of the school for science subjects, namely 70 .

Based on the results of the pre-test and post-test it can be seen that there are changes in student learning outcomes before using the learning module and after using the learning module. Changes and improvements in student learning outcomes that occur consist of increasing the average value and the percentage value of the minimum completeness criteria. The average pretest score was 66.44 , increasing to 71.37 after the post-test. For the minimum completeness criteria, the pre-test is $31.25 \%$ and $68.75 \%$ at post-test.

The following graph shows the average pre-test value before using the learning module and the average post-test score after using the learning module.

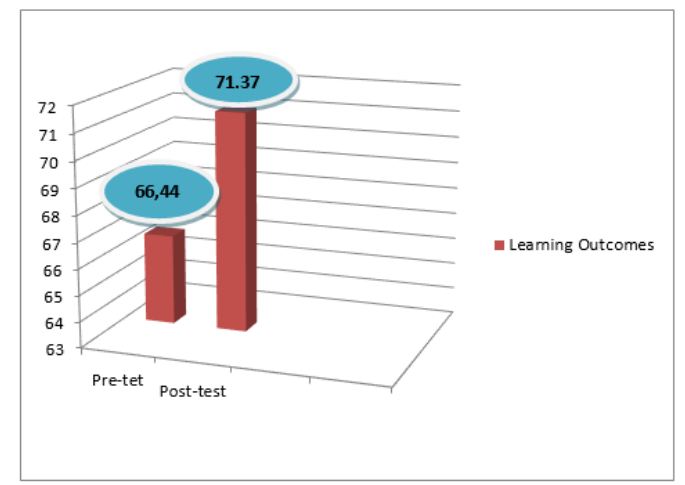

Fig. 2 Average Results of Pre-test and Post-test c. T-test calculation

The paired two-sample T-test is an analysis to test the differences between two paired samples. The sample in question is the value of the pretest and posttest results of students who have been obtained by the researcher.

Based on the data obtained, it is obtained the results of $t$ count $>$ table $(6.45>1.75)$ in other words, it can be concluded that there is an increase in learning outcomes of science subjects before learning and after learning to use the science module with problem-solving learning.

\section{B. Discussion}

Based on preliminary identification (preresearch) it was found that students in the sixth grade of State Elementary School 03 of Hulu Sungai in Ketapang Regency, said that the learning that took place was still teacher-oriented so that students were less active in learning. Whereas in the KTSP curriculum the teaching and learning process is demanded not only active teachers but students are also active in the learning process.

Plant breeding material in science subjects according to students is quite difficult to understand, to complete existing exercises and practicums it is quite difficult to solve the problem. It is because there is no effective learning source in solving the problem, so the researcher believes that by taking into account the conditions that are needed, students are required to have teaching materials in the form of modules, especially in the process of learning the breeding material.

Students need learning that can find their concept of plant breeding material so that students can participate in the active learning process. They also need a learning tool that can be independent and effective learning, one of which is in the form of a module. This module can help students to understand the concept by independent learning. Concept understanding can be known when students find themselves and apply them in their daily lives.

1. Module Development Plan

When creating a learning module, the design is the first stage or the initial stage that must be carried out by the researcher, because without a design in advance a learning module cannot be developed. A good design that is carried out will also get maximum development results and can be applied to learning by the learning objectives implemented.

The development of learning modules carried out in this study using the Research and development (R \& D) method adopted from Borg and Gall, which begins with conducting field studies and literature studies on the problems needed by students and finding solutions that can be given.

After a design is carried out properly and appropriately followed by the planning stage in the making of a learning module, especially the science module for plant breeding material for students in class VI of State Elementary School 03 in Hulu Sungai District, Ketapang Regency. Made by researchers.

After the learning module is completed in accordance with the design set, the next step is to validate with experts in their respective fields. Validation carried out included the validation of the learning module design experts, validation of material experts, especially science materials and validation of instructional media experts. Acting as a validator on the validation of the learning module design experts is the mother of Dr.Indri Astuti, M.Pd, a lecturer of the Postgraduate program in educational technology study program FKIP Untan Pontianak. The validator of the science materials expert was Mrs. Sri Supartini, M.Pd as a person at Pontianak 1 Public High School and the validator of the instructional media expert was Dr.Dede Surachman, lecturer of the Postgraduate Program of Educational Technology Study Program FKIP Untan Pontianak.

After validation, the next is product testing. In the small group trial involving as many as four students, several things were found in the stages of using modules such as clarity in the explanation of the breeding material and the implementation of problemsolving in this case was to provide a broader 
explanation of how to solve real problems in the plant breeding process.

After conducting the trial on the small group, the researchers gave questionnaires to the responses of students and then the researchers made improvements to the learning module based on the results of the students' questionnaire responses after the small group trial, after the researchers made revisions based on suggestions and input from the students in the small group then the researchers conducted a trial in a large group of all students in class VI of State Elementary School 03 of Hulu Sungai in Ketapang Regency, totaling 16 people.

In the trial phase of large groups of students were also given questionnaire response questionnaire to the learning process that has been carried out by using science learning modules with problem-solving methods of plant propagation material. After that, the researcher repeats or revises the module used based on the response and input of the students during the trial in the large group for improvement which includes clarity of examples of plant breeding that occurred.

2. Implementation of Learning Module

The module is implemented in class VI of State Elementary School 03 of Hulu Sungai in Ketapang Regency which is grouped into two groups, namely a small group consisting of 4 students and a large group consisting of 16 students. In small groups and large classes are given learning modules on the same material.

Before the learning process using modules is implemented, the first step carried out by the teacher as a facilitator is to conduct preparation or conditioning activities such as preparing modules, plant examples that will be used as learning resources with problem-solving methods and so on, then the teacher gives greetings, motivates and explained the purpose of learning and explained again the science learning module with the problem-solving method to be used.

Before the learning process is carried out the teacher and students agree to pre-test all students or the entire subject of the researcher find out the initial conditions of the students before acquiring learning by using modules. After students work on the pretest problem, a trial is held on a small group, then the responses and input from the students on the module and the implementation of problem-solving methods are obtained, and the researcher makes improvements to the responses and input from the students. Then the researcher returned to the learning process in a large group that involved all students and returned in the end to make improvements or revisions to the module based on suggestions and input and findings from students.

The next step the teacher explains again the important points contained in the module, after which students begin to do learning activities. After arriving at the next learning activity, the teacher asks students to work on the competency test in the module.

At the end of the learning, students are asked to fill in the student response questionnaire using the science learning module with problem-solving methods. From the results of the small group trial, some suggestions and comments were made as revisions by the researchers. The revision is done as a refinement of the product to get optimal results from the product being developed. The revised module is then re-tested in a large group of 16 students or all research subjects. After testing the large group at the end of the learning, a post-test was conducted to determine the level of success of students absorbing the material by using science learning modules with problem-solving methods.

From the activities that have been done, it is very clear that the teacher is only as a facilitator the rest of the students can learn independently by using existing modules, from the findings of the learning process carried out clearly seen that the learning module is a tool or means of learning that contains material, methods, limitations learning materials, learning instructions, exercises and how to evaluate expected competencies that are designed systematically and interestingly, easy to read and easy to understand to achieve the expected competencies and can be used independently.

3. Learning Outcomes Using Modules

Learning outcomes are a benchmark for achieving the learning objectives. To find out the student learning outcomes of plant breeding material after using the module, the research instrument was used in the form of pretest and posttest questions.

The pretest is done to know students' abilities before using modules. From the results of the pretest, the average score of students is 66.44 , which means that there are still many students who have not achieved minimal mastery. The completeness value obtained is only $31.25 \%$ of the number of students. It means that the results achieved by students are still low classically because they have not reached the maximum desired grade, which is at least $65 \%$.

After doing the pretest, the researcher carried out the learning process using the science learning module with problem-solving methods according to the planned time. After completing the learning process, it is done in 2 meetings, then the teacher as the researcher returns to posttest, the results of the posttest were obtained with an average score of 71.73 with the classical completeness score is $68.75 \%$. It is clear that there has been an increase in the results of the pretest that was done previously after the learning process using the module.

Based on the pretest and posttest scores obtained, then the researcher conducted a T-test to see whether there was an increase or not the value obtained by the students before using module and after using the module. The results obtained based on the 
calculation that is the value of $t$ count $>$ table (6.45> $1.75)$ at $\alpha=0.05 \mathrm{df}=\mathrm{n}-1$ means that the value of $\mathrm{t}$ arithmetic obtained is greater than the value of t table, then it can be said that there was an increase in the evaluation value of science subjects, especially plant breeding material for students in class VI of State Elementary School 03 of Hulu Sungai in Ketapang Regency, before using the module, after using the science learning module, the breeding material in the learning process or there were differences in the results of learning the plant breeding before and after learning to use the science module the problemsolving method.

The learning outcomes obtained show that the desired learning objectives experience achievement, namely students have improved both in terms of knowledge in learning, this is in line with the opinion according to Sardiman (2010: 26) that learning goals are to gain knowledge characterized by thinking skills, concept planting and skills that are physical or spiritual and the formation of mental attitudes and behavior of students, will not be separated from the question of planting values.

\section{CONCLUSIONS}

Based on the results of research conducted can be concluded as follows:

1. Based on the validator assessment, the module design experts obtained an average value of 3.49 , which means that the design of the learning module that has been made is good and can be used in the science learning process of plant propagation material. The results of data analysis carried out from material experts; the instructional materials developed obtained a total average score of 3.39 with good and valid qualitative criteria, although there are still many things that must be revised in accordance with the suggestions and comments from the validator. Then the suitability aspect of the module material has very good qualitative criteria with an average value of 4.00 teaching material assessment items so that it can be concluded that the media design has a consistent and harmonious design and this media is suitable for use.

2. In the implementation of learning in the classroom, the teacher is only as a facilitator the rest of the students can learn independently using the existing module.

3. The results obtained based on the calculations performed is the value of $t$ count $>$ table (6.45> $1.75)$ at $\alpha=0.05 \mathrm{df}=\mathrm{n}-1$ means that the value of $\mathrm{t}$ arithmetic obtained is greater than the value of $\mathrm{t}$ table, then it can It was concluded that there was an increase in the value of the evaluation of science subjects, especially the material of plant breeding for students of class VI of State
Elementary School 03 of Hulu Sungai in Ketapang Regency.

\section{REFERENCES}

A.M, Sardiman. 2010. Interaksi dan Motivasi Belajar Mengajar. Jakarta: PT Raja Grafindo.

Borg, W R \& Gall, M D. 2005. Educational Research: an Introduction, Fourth Edition. New York: Longman. Inc.

Hamdani. 2011. Stategi Belajar Mengajar. Bandung: Penerbit Pustaka Setia.

Hamruni. 2012. Strategi Pembelajaran. Yogyakarta: Insan Madani.

Nawawi, Hadari. 2012. Metode Penelitian Bidang Sosial. Yogyakarta: Gadjah Mada University Press.

Peraturan Pemerintah Nomor 19 Tahun 2005 Tentang Standar Nasional Pendidikan.

Sugiyono. 2012. Metode Penelitian Kombinasi (Mixed Methods). Bandung: Alfabeta.

Sukmadinata, Nana Syaodih. 2005. Metode Penelitian Pendidikan. Bandung: Penerbit PT Remaja Rosdakarya. 